\title{
Very Low-Density Lipoprotein Receptor
}

National Cancer Institute

\section{Source}

National Cancer Institute. Very Low-Density Lipoprotein Receptor. NCI Thesaurus. Code C115015.

Very low-density lipoprotein receptor ( $873 \mathrm{aa}, \sim 96 \mathrm{kDa}$ ) is encoded by the human VLDLR gene. This protein plays a role in the modulation of both reeling signaling and lipoprotein endocytosis. 